\title{
Special Techniques \\ and Technical Advances in PET/CT Imaging
}

Editor

RAKESH KUMAR

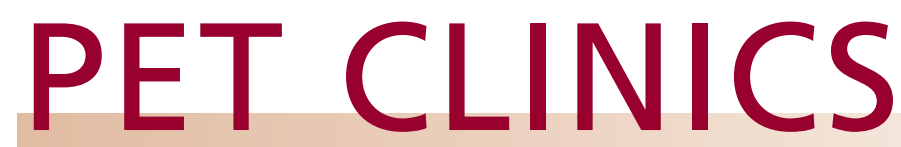

www.pet.theclinics.com

Consulting Editor

ABASS ALAVI

January 2016 • Volume 11 - Number 1 